embryo. I have had occasion lately to examine the brain of this abnormal specimen with greater care, and I have come to the conclusion that my first impressions were not correct. The brain is there, complete, but I am convinced that the folding of its walls is not due only to collapse consequent on its condition, but that there is also some dilatation of all the main cavities of this portion of the central nervous system. The cerebral vesicles moreover, although they are quite definitely and normally apparent in their hinder parts, do not seem to be properly formed further forward, though this appearance may be partly produced by dilatation of the telencephalon. The general structure of the brain tissue seems to be quite normal for its stage. The abnormalities of the central nervous system do not seem to be very great, but I think their existence should be put on record.

Yours, etc.,

IDA C. MANN, M.B., B.S.

\title{
THE INTERIM REPORT OF THE COMMITTEE OF THE MINISTRY OF TRANSPORT ON LIGHTS ON VEHICLES
}

\section{To the Editor of ThE British Journal of Ophthalmologi}

SIR,-I would draw attention to the penultimate paragraph of the annotation in the present number of the Journal on the Interim Report of the Committee of the Ministry of Transport on Lights on Vehicles. The writer of the annotation says that when two motor cars approach each other with brilliant headlights it is becoming fairly general amongst motorists to turn out their headlights when passing each other so that the danger of either car running into anything during the time that the eve is regaining its dark adaptation is minimized. The real fact of the matter is that there is at present among motorists a perfect hullabaloo about the extreme danger of the present conditions, in which not only is there no definite rule as to this dimming or extinguishing, but also a wide divergence of opinion as to its advisability. It would not matter so seriously if the motorist's convenience were the only point in dispute. One may agree that the pedestrian can look after himself if he chooses to flatten himself against the hedge, but the greatest danger is to the cyclist unless he is prepared to do the same. Consider the conditions on a narrow dark road without a footpath. Two cars are about to meet with headlights on, so that the drivers, if they shade the eyes from each other's glare (which can often be done with the hand, the peak of the cap or some special device), can see everything that may be on the road. One of them extinguishes his headlights; and; as he passes the other 
car finds himself in almost Cimmerian darkness and more or less dazzled and " disoriented." Now it is an unfortunate and very stupid fact that as the law stands at present the cyclist does not require to carry a rear light. What is to become of him if he happens to be just about the point of meeting of the two cars and travelling in the same direction as the one whose driver has extinguished his headlights and cannot see anything? A man with a wheelbarrow or a woman with a perambulator is in exactly the same predicament, to say nothing of the pedestrian and the dog, who are both unlighted. Owing to the present interregnum between D.O.R.A. regulations and the new regulations which will come in time, matters are worse than need be, but most of those who know the meaning of dark roads full of all sorts of traffic and possibly without footpaths have no use for switch twiddling courtesies. The latter may be ${ }^{*}$ good enough for town and suburban driving, but are in the highest degree dangerous on really dark roads.

$$
\text { Yours, etc., }
$$

\section{ERnest Thomson.}

[A leader on this switching off of headlights was published in the Autocar of November 19, 1921, subsequent to the writing of above.-Enitor.]

\section{IMPROVEMENT OF VISIBILITY}

\section{To the Editor of The British Journal of Ophthalmology}

SIR,- In the present number of the Journal I observe that there is an Annotation entitled " Improvement of Visibility," in which the polarization of light from reflecting surfaces is referred to. It may be a well-known fact, but, whether so or not, I have for long had the idea that polarization is the cause of the excessive skin bronzing which is associated with fishing excursions and sea voyages. Now, the point of this letter is that if such skin bronzing should turn out to be materially lessened or prevented by the wearing of tourmaline spectacles, we are going to have not only that rest to the eyes to which the writer of the annotation refers, but also two light patches about the skin of the lids which may give us when on holiday somewhat the appearance of the famous " white-eyed Kaffir," with this difference that whereas he had, I believe, one white eye, we shall have two.

Yours, etc.,

ERnest Thonison. 